\title{
NO RITMO DO ANFÍON DE JOÃO CABRAL DE MELO NETO: ACOLHENDO/RECUSANDO A HISTÓRIA
}

\author{
Cristina Henrique Costa \\ (UNICAMP)
}

Anfion ${ }^{1}$ chega a um deserto caracterizado como total, no intuito de nada criar; surge o Acaso, faz soar a flauta do herói e cria a cidade de Tebas; o herói rejeita a cidade criada, indaga sobre como criar, mas joga ao mar a flauta.

Fábula de Anfíon, pela posição de destaque que ocupa na obra de João Cabral de Melo Neto, integrando por um lado a coletânea Psicologia da composição, e cronologicamente composto, por outro lado, entre dois livros muito conhecidos, $O$ engenheiro e $O$ cão sem plumas, apresenta-se como um poema narrativo complexo e consistente, já muito comentado pela crítica que não consegue ser unânime na interpretação, quer da negatividade do conteúdo narrado, quer da positividade do projeto do poema ${ }^{2}$ Ora, foi através da observação de como a "passagem crítica" pela Fábula cabralina de 1947 põe à prova nossa capacidade de compreensão da mensagem clara do texto, que surgiu a idéia do presente artigo.

${ }^{1}$ Adoto aqui a grafia de José Guilherme Merquior em A astúcia da mimese.

${ }^{2}$ Quanto à negatividade, ver: NUNES, 1971, pp. 46-51; BARBOSA, 1975, pp. 57-70; SECCHIN, 1985, p. 6o; LIMA, 1995, p. 233. Quanto à positividade do poema enquanto projeto, ver por exemplo FERRAZ, 200o. Lista não exaustiva. 


\section{Ler Fábula de Anfíon, ler João Cabral}

Tento aqui, de fato, reler o poema de João Cabral de Melo Neto insistindo na perplexidade frente às ambiguidades que o texto impõe, com a convicção de que tais dificuldades inerentes ao poema é que justificam o risco de sua interpretação. O que pretendo evitar, antes de tudo, é a conivência prévia entre o autor e o leitor, quando ambos se mostram aparentemente interessados num pacto de clareza que começa por selecionar, num poema estruturalmente denso como este, os elementos ou instrumentos daquilo que não deixa de servir à limpidez de um discurso que não está no texto, e apenas o acompanha miticamente. Contrariando este pacto, será necessário aqui reconhecer certos tropeços para deliberadamente não assumi-los, reenviando-os ao remetente. Desta maneira, as dificuldades não serão apagadas nem dissolvidas, para melhor dar a ver o papel inevitavelmente arriscado do leitor.

Cabe aqui definir primeiro - pois quem não vê dificuldades no texto tampouco as enxerga em sua própria leitura, o que se entende por problema de interpretação e dificuldade do texto: não se pode duvidar, por um lado, que certa obscuridade da Fábula de Anfíon esteja relacionada com a insuficiente descriminação, pelo crítico leitor, daquilo que está dito pelo texto, e daquilo que não está exatamente dito nele e por ele. Esta mistura de elementos heterogêneos (o dito e o não dito) parece tanto mais dificultosa para a leitura quanto mais se afirma, paralelamente, como verdade intrínseca do próprio texto. Pois nenhuma das leituras que conheço desta Fábula, salvo engano meu, atém-se aos elementos apenas textuais, embora muitas, salvo engano meu, pretendam falar apenas disso. O presente artigo não versa diferente: é sem ilusão quanto à possibilidade de ser absolutamente fiel ao texto, mas tenciona pelo menos considerar esta infidelidade como característica e dificuldade do próprio texto, tentando localizar o momento a partir do qual ocorre a saída escolhida para fora dele.

Por outro lado, se está ainda para nascer o crítico desrespeitoso da autoridade cabralina a ponto de ler nos poemas do pernambucano esdrúxulas coisas - no lugar de sua costumeira estética do cálculo racional e da linguagem metapoética que a veste, o que se pode fazer por enquanto é sugerir que talvez, inversamente, não seja conveniente - para dar conta da leitura de algo que se apresenta tão poético, economizar esforços no sentido de esclarecer as razões que obscurecem até o impedimento a distinção do que está fora e do que está dentro do poema. Eis aí uma dificuldade tipicamente cabralina, e de porte: ao mesmo tempo que o texto do pernambucano prende o leitor, pede-lhe uma mobilização por fora de 
preconceitos estéticos, poéticos e ideológicos. A liberdade de esco-l(h)er não consiste nem em aderir nem em recusar os princípios desta estética, e sim no eventual revide de uma saída textual controlada e necessariamente relativa, feita com a consciência de algumas armadilhas retóricas que obrigam também a permanecer naquilo que é um texto sem saída. Pois, de fato, não se escapa totalmente à estratégia do poema cabralino, a não ser nele ficando, até conseguir desmistificá-lo enquanto texto.

Para resumir a dificuldade proposta: enquanto leitura do mecanismo de persuasão montável e desmontável, ler o pernambucano exige a distância racional da delimitação de um fora e de um dentro do poema; mas esta distância é o próprio efeito produzido de dentro do texto, e aponta para a dificuldade extrema de obtê-la. Ambas as coisas - distanciamento e envolvimento, integram a captação retórica que precisa ser localizada enquanto ponto de partida das dramatizações da cena poética de João Cabral.

Dizendo de outro modo, analiso aqui a possibilidade de considerarmos a racionalidade e a clareza árida de João Cabral como apenas um dos elementos de sedução e de prescrição textual, ao lado de outros, e em todo caso situado apenas no limiar de sua leitura. Em suma, a relação poética que o pernambucano mantém com a ideia de racionalidade só poderá ser melhor captada quando for compreendida enquanto prescrição, e um dos caminhos para este entendimento é mostrar que seu texto só consegue prescrevê-la proibindo-a, inserindo-a numa rede semântica muitas vezes obscura ou ambígua, onde ela passa a ser a saída ingênua tentada por um leitor que, desejoso de escapar à confusão, e legitimamente irritado com a indeterminação semântica de um discurso, esquece que sua saída pelo recorte da clareza já estava exatamente prevista pelo próprio texto, desde o estabelecimento de seus lugares comuns. Neste sentido, o presente artigo quer paradoxalmente avaliar as possibilidades de não sair do texto muito rápido, desobedecendo às soluções de leitura mais fáceis.

Uma observação relativa à gênese da poesia cabralina impõe-se aqui: vale lembrar que foi o desconhecimento daquilo que se pode definir, no sentido de Michel Charles (CHARLES, 1977), como prescrição de leitura, que levou a ignorar a importância do papel da indeterminação em muitos poemas do pernambucano. Este problema crítico afetou prioritariamente a leitura do primogênito Pedra do sono, publicado em 1942, onde o poeta já se eximia nesta arte estratégica de prescrever o indeterminado. Como sugeriu John Gledson (GLEDSON, 1978, p. 44) há muito, a questão daquele livro não era nem psicológica nem filosófica, era retórica e estética: "This indeterminancy constitutes the real difficulty of Pedra do sono; a first step towards understanding the book can be 
made by realizing that it is deliberate (...)”. Mas, ao afetar o livro de 1942, o esquecimento da retórica da indeterminação reiterou-se na leitura de obras muito posteriores - não só na de Fábula de Anfíon como também na de vários poemas de $A$ educação pela pedra, por exemplo.

Verificando precisamente a existência desta prescrição de indeterminação no texto da Fábula que nos interessa, o problema de leitura toma a figura de uma conflituosa convivência entre a estética positivista do cálculo racional sugerida ao mesmo tempo que proibida, e a lógica do discurso negativo que parece desejá-la para melhor censurá-la. Elevando este último à dignidade de categoria estética, e rebaixando a primeira à condição de possível vício psicológico do herói, o texto do poeta turva de propósito a univocidade de sua mensagem através de uma copresença perturbadora dos valores teóricos e práticos que na estética racionalista não se encontram, cultivando os efeitos paradoxais e implosivos de um texto psicologicamente obcecado pelo racional e no entanto poeticamente aproveitável graças às ressonâncias subjetivas que ecoam em sua prescrição de indecisão. Fiquem os críticos com a inglória tarefa de harmonizar um discurso sobre a arte de criar racionalmente que realiza performativamente seu contrário, deve estar rindo até hoje o poeta lá no céu. Mais seriamente, a divisão clara das tarefas do racionalismo poético: por um lado, criar racionalmente, como tarefa de autor, e por outro lado, receber efeitos irracionais, como tarefa de leitor, é substituído na Fábula pela transferência de ambos os papéis para o domínio do leitor, o que também vem a significar a convivência de ambas as coisas na dimensão autoral implícita. Isto, que costumamos chamar de visibilidade dos mecanismos racionais da criação poética de João Cabral, nada mais é que parte de uma estratégia de persuasão da racionalidade absolutamente problemática do texto. Quem não se deixa persuadir só pode ser obscuro.

Em decorrência disto, embora o poema "fale" de criar racionalmente, fica-se impedido de apostar tanto na racionalidade do discurso quanto na irracionalidade do poema. Nem fracasso, nem sucesso: aplaudimos inversamente a eficiência retórica de uma indeterminação sedutora, a qual, prescrevendo que se leia uma e outra coisa, prescreve sobretudo certa sujeição à ficção de totalidade de um texto que se basta por dar a impressão de dominar o processo completo de simbolização dos valores poéticos, criando-os arbitrariamente, mas fazendo-os passar por naturais; um texto concebido como preenchimento de todas as oscilações entre o sim e o não, que se apresentam como oscilações ontológicas determinantes do não ser e do ser, para definir no plano cognitivo a clareza e o mistério, no plano psicológico, o vazio e o cheio, e no plano ético, o negativo e o positivo. Um texto, em suma, sem saída. 
Uma segunda observação faz-se então necessária, a fim de evitar a confusão entre gênese e cronologia: inserir a história desta composição numa continuidade da obra cabralina, a meio caminho entre surrealismo e poesia social não poderia ser aqui a solução para explicar a indecisão do poema, se queremos que a condição para lê-lo seja permanecer nele, pois o postulado implícito de qualquer leitura cronológica é a existência de causas antecedentes ao texto, a partir das quais o leitor poderia configurar o discurso das razões estéticas de ser da Fábula de Anfíon. Insiste-se aqui inversamente na retórica do texto enquanto exercício de autoridade textual que desautoriza a especulação sobre eventuais causas antecedentes, muito vinculadas ainda ao conceito de intenção psicológica do autor. Isto não irá significar que a leitura não se apoie em elementos que possam estar fora do texto, muito pelo contrário: qualquer retórica precisa de alguma fronteira entre dentro e fora, mas o objetivo da leitura crítica é investigar como controlar o processo de decisão e escolha pelo leitor apesar da leitura, e não pelo autor, deste ponto e de suas saídas.

De várias formas a retórica cabralina convoca na Fábula o esquema da indeterminação e de muitas maneiras não autoriza uma leitura totalmente desambiguada. Não me atenho aos dois esquemas mais óbvios: a moral da história (ninguém saberá dizer se Tebas é boa ou má, nem se Anfíon fracassa ou obtém êxito); e a psicologia do herói (pois ninguém saberá dizer se ele está satisfeito ou não). De fato, estas indeterminações, para se tornarem interessantes, supõem que o poema esteja apenas narrando alegoricamente as aventuras do ato de criar, mas como o texto não obriga a crê-lo, posto não se estabilize como mito da criação, não há necessidade de aprofundar a questão.

Justamente, a indeterminação semântica é mais profunda e atinge a legibilidade do estatuto do discurso, pois, inversamente, a revisitação cabralina do mito anfiônico pelo ângulo da ambivalência do gesto de criar com o qual se articula a narrativa pernambucana prescreve a insistência do texto no mito não mítico, no mito que não joga seu papel de criador e de introdutor da História, no mito que se autodestrói, nada originando, e permanecendo apenas Fábula. Embora o mito (origem coletiva da linguagem) seja também aqui mais uma figura do desaparecimento elocutório, sua corrosão enquanto gênero contamina a categoria do histórico, e todo o problema é então o de saber se mito e história se anulam mutuamente no poema, substituídos por algo que seria da ordem da Poesia ${ }^{3}$ ou se a dupla negação crítica de mito e história pela Fábula

${ }_{3}^{3}$ Como faz Valéry em Amphion. 
aponta para certa significação da historicidade subjetiva do poema, sem resgate pela Poética. A alternativa em si é parte da estratégia retórica da indeterminação: o poema não decide se fala de Mito ou de História; isto é, não autoriza qualquer definição teórica, recuperada no pensamento da Poesia capaz de essencializar o discurso da Fábula, produzindo o conceito de História em geral, ou de Poesia em geral. Mas ao desautorizar a generalidade de uma definição, o poema talvez aponte, por isso mesmo, para a subjetividade de uma posição crítica altamente poética.

Neste sentido, antes mesmo de qualquer interpretação, já se pode sugerir que Fábula de Anfíon recusa e acolhe a História: recusa-a, como conceito, como teoria, como conteúdo determinado e determinante para o poema; mas acolhe-a, como posição de historicidade crítica.

\section{A retórica da indeterminação}

Entrando no texto: é concretamente impossível contar a "história" da Fábula. Pois, na verdade, o próprio poema inscreve na sua "carne textual" o resumo de sua narrativa na medida em que oferece, paralelamente à estrutura estrófica principal, uma série de rubricas sinópticas que, por encabeçarem os diversos segmentos, apresentam-se desde já como resumos ou retomadas do "conteúdo da história narrada": Anfíon chega ao deserto, o deserto, sua flauta seca, etc. A função em princípio tautológica destas rubricas não impede o jogo instaurado entre um fora e um dentro da narrativa poemática, a partir do qual se prescreve certa leitura, que ao mesmo tempo proíbe o papel de interpretação do leitor. Num único gesto, como se preciso círculo, o que convida também inibe.

Tudo se passa como se o próprio texto buscasse prevenir uma compulsão inevitável de "ler com dúvidas", compulsão que as numerosas marcas (prosódicas, sintáticas e semânticas) não deixariam de reforçar, não fosse a ordem do diretor ${ }^{4}$. E não obstante tais hesitações constituam o próprio texto. Desta maneira, Fábula de Anfíon apresenta-se como narrativa paradoxalmente irresumível e, logo, insolúvel, na qual o artifício retórico consiste em preencher "o espaço do silêncio" prenhe de sentido com assertivas de aparência unívoca, operando com a categoria do curtocircuito da dimensão sugestiva, que no entanto é de certo modo a própria "filosofia" do poema. Construindo certa totalidade narrativa, que inclui

\footnotetext{
${ }^{4}$ Refiro-me a um poema da juventude de João Cabral: Pirandello I; nele, um diretor "dá uma ordem" (não olhem para a objetiva!) que, no entanto, não ordena a percepção do eu lírico do poema (MELO NETO, 1994, p. 806).
} 
o fora e o dentro da história narrada, esta dualidade de vozes é a receita retórica que dá a chave de leitura, esclarecendo de que forma um texto que está comandando de dentro o olhar do leitor, pode, ao mesmo tempo, estar acenando para a necessidade de interpretação (que as rubricas sinópticas performativamente realizam) e estar impedindo a própria interpretação (por imposição de um conteúdo discursivo que proíbe o poema).

É neste sentido que a leitura da Fábula de Anfíon pode se fazer pelo prisma da exploração das discordâncias semânticas entre, por um lado, as diretrizes sinópticas e, por outro lado, as estrofes do poema: isto é, a própria dissonância, ao prescrever certa leitura, deve ser tratada em primeiro lugar como parte da estratégia do texto. Entre várias entradas possíveis nesta questão, escolho a fundamental dissonância entre a rubrica sinóptica que encabeça a terceira parte do poema, intitulada Anfíon em Tebas, e as seis primeiras estrofes desta mesma terceira parte.

Ali, deduz-se facilmente a problematicidade do texto (MEYER, 1999, pp. 319-321) do fato de que a prescrição de leitura da rubrica sinóptica - que Anfíon, neste momento da narrativa, estaria buscando em Tebas o deserto perdido - choca-se contra a prescrição de leitura da parte estrófica, onde, graças às pausas poéticas, nada leva a crê-lo: Anfíon/ ante Tebas/ como/ a um tecido que/ buscasse adivinhar/ pelo avesso/ procura/ o deserto/ Anfíon ${ }^{5}$. Ou seja, o ritmo das estrofes resiste ao poder de exclusão exercido pelos signos da rubrica.

Estas dissonâncias acabam problematizando também (para o leitor que quiser assumi-las como problema) a relação entre outras rubricas sinópticas e outras estrofes; e finalmente, a totalidade semântica do poema revela-se afetada pela tensão entre, por um lado, o que está sendo dito, e por outro lado, o suplemento de informação, que tanto pode se apresentar como suplemento objetivo ou explicativo (as rubricas) quanto como suplemento poético ou sugestivo: pausas, silêncios, cortes de versos, etc. Desta maneira, a tensão acaba se transferindo para o campo da dissonância entre a semântica estrófica e a sinóptica, impossibilitando a identificação do literal ali mesmo onde o literal é exigido como prescrição de leitura. Por exemplo, a rubrica Lamento diante de sua obra choca-se com a narrativa estrófica, onde nada indica que Tebas seja obra de Anfíon.

${ }^{5}$ Elementos sugestivos: ante Tebas (e não em Tebas); Tebas como a um tecido que (possibilidade de metaforização de Tebas/tecido); buscasse adivinhar (ausência de sujeito para o predicado verbal); pelo avesso procura (o objeto da procura pode ser o avesso); procura o deserto (quem procura é o deserto); o deserto Anfíon (deserto como qualidade psicológica de Anfíon). Foram consideradas como pausas tanto as vírgulas quanto as cesuras sintáticas provocadas pela organização da narrativa em versos. 
Algo parecido ocorre com o Deserto, que em função deste mesmo processo de dissonância pode ou não ter sido perdido.

Hoje, já não se pode interpretar estes fatos poéticos a partir do argumento de reconstituição, abusivamente ingênuo, do que João Cabral queria dizer, mas em contrapartida, uma das possíveis direções interpretativas consiste em ler tais prescrições pelo lado de sua eficácia. E nesta perspectiva, levando a sério o processo retórico, lê-se no texto que a Tebas de João Cabral, nascida de um esforço poético para não decidir nada sobre o estatuto da obra e do criador, não é definível como artefato. Ou seja, não se apresenta como objeto artístico criado a partir da decisão espiritual do criador. Pouco importa se Tebas é arquitetura, música ou poesia, como também pouco importa que ela se deixe captar através do jogo diferencial entre estas artes. Em ambos os casos, o postulado racionalista, de tipo valéryano, consistiria em considerar o objeto artístico, qualquer um, como dedutível de certa atividade pensante, vista como causa de sua existência e inteligibilidade. Em outras palavras, a capacidade para discriminar e selecionar as leis definidoras do objeto criado enquanto artefato artístico é sempre obra de um espírito racional que projeta alguma coisa. Ao contrário, o Anfíon cabralino nada projeta; seu lamento faz-se ante o que se tem, e não antes do que se quer ter. Ora, desta forma, a Tebas de João Cabral, suspensa ao jogo de suas dissonâncias e ritmos, não sendo artefato, obriga a indagar com outros olhos como funciona a carga negativa implicada na significação semântica do poema.

Explico-me melhor: na perspectiva da fenomenologia valéryana, a passagem pelo momento de negação da positividade do real é um ato espiritual indispensável à construção de uma relação racional ativa com o objeto criado. Isto é, relação só se torna possível quando ocorre certa negação de realidade imposta pelo espírito racional: "construire existe entre un projet ou une vision déterminée et les matériaux que l'on a choisis. On substitue un ordre à un autre qui est initial, quels que soient les objets qu'on ordonne" (VALÉRY, 1919, 79).

Ora, se a Tebas do Anfíon pernambucano não é um artefato de tipo valéryano, se não é obra de criador previamente negador, é outro tipo de coisa, descortinando outro campo de referência, acenando para outra ideia de atividade e passividade no ato de criação. Não se trata portanto apenas de dizer que no poema de Cabral Anfíon foi vencido, na medida em que dizer isto significaria referir-se ao poder de negar inerente ao ato de criar, no sentido de fabricar. Porém, se admitimos que o negativo trabalha em outra esfera - numa esfera em que ele nunca coincidiu idealmente com alguma posição de controle racional do herói, transfere-se para outro lugar, que não o espírito do criador, a atividade de negação referida, tanto 
em sua capacidade de êxito quanto em sua possibilidade de fracasso. Ou seja, para que o negativo persuada no poema, é preciso reconhecer outro foco, que não o espírito negador, como lócus produtor do negativo. Este lócus, na Fábula, é representado pelo Acaso - não é Anfíon. Compreender o sentido deste Acaso é ler o poema.

Isto dito, do que está falando este poema do Acaso? Se não está falando da fabricação artística espiritual, é que não há projeto nem objeto claro. $\mathrm{O}$ que o Acaso cria não está em causa, e como estão dizendo os segmentos citados, interessa mais ao herói certa busca metafórica ou imaginativa (como a um tecido que buscasse adivinhar) cujo objeto é o avesso. E note-se que o avesso, na falta de objeto definível, sequer pode ser considerado como o contrário de alguma coisa. Ou seja, tudo se passa como se o avesso fosse o homólogo de algo que está no poema sem ser nomeado por signo. O Acaso cria o desejo do avesso (de busca, de procura...), como já se disse, ante (não é antes) aquilo que se tem, Tebas.

Ora, se a questão da busca não opera segundo os moldes de um modelo do que se busca (um ideal utópico, um objetivo de racionalidade, uma essência estética), o desejo que bebe em outras fontes não tem como fracassar enquanto discurso. Anfíon indaga no final: como fazer (...) como faz? Nisto consiste precisamente a eficácia retórica de seu enigma - afirmar o desejo de fazer como, mas negando paralelamente tanto o projeto quanto o objeto da imitação. Em suma, o enigma da cachorra da esfinge é um desejo mimético sem projeto construtivo e sem negação espiritual; isto é, sem as duas faces definidoras de uma atitude racional frente à criação artística.

Ora, assim como Tebas não é artefato, tampouco a Fábula de Anfíon se estabiliza como artefato poético para ser lida em função de um modelo racional de fabricação. Anfíon, buscando, pede outra coisa ao leitor, pede que ele também não tenha projeto de leitura. Pede, sem dizer o quê. Esta inadaptabilidade aos elementos discursivos exógenos, porém pedinte de fidelidade - característica idiossincrática que faz todo o charme do pernambucano impossível e teimoso, é feita para dissuadir de perguntar coisas que não são perguntas do poema e que não terão respostas no texto. Por exemplo: Anfíon vai ao Deserto porque não quer criar, ou porque quer criar puramente? O Acaso é fruto de sua alva distração, ou é figura da realidade? Ou ainda: o que o poeta quis dizer? Não são alternativas, e enquanto forem perguntadas como tais, a resposta que estas questões autorizarão será sempre não se sabe. É a esfinge da indeterminação deliberada. Os próprios termos criar e acaso precisariam ser requalificados em outra esfera; estão viciados pela prática conceitual, e contaminados pela pretensão de racionalidade. 
Por isto, é importante reconhecer que aplicar a Rhétorique de la lecture (CHARLES, 1977) ao caso preciso de João Cabral resulta em aceitar que o discurso poético, não se firmando unívoco, inscreva na leitura este processo de indeterminação. Isto é suficiente como desmistificação do mito da racionalidade do poeta, embora não seja ainda suficiente para ler seu poema. Pois reconhecer a indeterminação ainda faz inevitavelmente do leitor perfeito o autor de um texto irritante; obedecer à regra da indecisão leva o leitor, tão falante, a ficar mudo como Anfíon, passando do reconhecimento significativo das dissonâncias à sua própria indecisão de leitor performativo, preso na armadilha da falta de um poema-artefato claro, para ler e comentar. Um leitor ainda muito preso ao preconceito racionalista que se condensa na palavra Acaso.

\section{A História de suas leituras}

Se, por um lado, não há nada a fazer com a indecisão prescrita eficientemente pela leitura do texto - a não ser sofrê-la, toda a questão passa a ser, por outro lado, a de saber se é possível, e em que medida, sair do texto pelo texto. Para tanto, é preciso ser coerente com a falta de distribuição racional das tarefas no poema, explorando a indeterminação na figura de sua fragilidade convidativa, como processo controlado de identificação, isto é, de imaginação da inclusão do autor como leitor de si mesmo, afetado enquanto tal pela eficácia de seu próprio texto.

Paul Ricœur (1985, pp. 228-263), analisando a Rhétorique de la lecture, e interpretando-a como pensamento da eficácia retórica que acena para sua própria fragilidade, propõe conceber o ato de leitura enquanto ultrapassagem da retórica da leitura em direção de certa hermenêutica crítica, através da passagem do mundo do texto para o mundo do leitor. Nesta passagem, lembremos que se corre sempre o risco da violência contra o texto, e por isso mesmo a operação precisa ser realizada sob o controle autocrítico e autorreflexivo do leitor. A questão é no fundo a de saber como refletir sobre a articulação entre os excessos de sentido e a significância destes excessos para um leitor em posição de historicidade, com um pé no mundo real e fora do texto. Pois não há fragilidade de texto sem leitor frágil. E no caso da Fábula de Anfíon, talvez ambos possam se cruzar na crítica do esquema da fabricação racional como ideologia de leitura.

O poema de João Cabral, de fato, fala demais e muito além de seus signos. Fala demais, em primeiro lugar, porque Fábula de Anfíon mergulha profundas raízes na rejeição, pelo pernambucano, da Poética dualista de 
Paul Valéry. Pois por trás das concessões valéryanas à emoção poética que o estilo simbolista adorna, João Cabral lê (e com toda razão) a exigência de ruptura irreparável entre a criação espiritual, por um lado, e o obscuro sentimento real (ou sentimento do real), por outro lado. Em Valéry, o sensualismo é o reverso do racional, mas como ambos são irreconciliáveis, consuma-se um radical divórcio entre o espírito negador e a realidade. O pernambucano vê nisto um risco que pode se virar contra sua própria e pessoal "decisão de racionalidade", uma vez que, lançando seu olhar de identificação subjetiva, não encontra em Valéry teórico argumentos nem motivos racionais de não copiá-lo, negando tudo racionalmente embora suspeite estar com isto macaqueando o francês: "Toutes choses se substituent - ne serait-ce pas la définition des choses ? ( ) notre personnalité elle-même ( ) n'est qu'une chose” . (VALÉRY, 1919, p. 33). Tudo se substitui, inclusive o mundo de João Cabral? Ao sol do deserto, que tudo seca sem ser fonte de nada, cristaliza-se nervosamente a flauta seca. Esta é a leitura que João Cabral faz de Valéry: lido por Valéry, ele é estéril como um deserto sob o sol; leitor de Valéry, ele é duplamente estéril, como uma flauta seca. O pernambucano, ao seu modo, também procura atormentado a saída poética para a coação da retórica da universalidade simbolista.

Fala demais, em segundo lugar, na medida em que esta questão, para ser entendida, requer o confronto - trazido ao universo de João Cabral, entre Valéry e Mallarmé. Como é sabido, a origem do gesto negador simbolista, em sua radicalidade, remonta a Mallarmé, ao qual de fato João Cabral também remonta, na sua pessoal tentativa de leitura do valor poético da negação. Deste ponto de vista, não há como não ler a Fábula (e muitos outros poemas de João Cabral) como sucessão dramatizada dos momentos sintéticos da Poética mallarmaica: desaparecimento vibratório, desaparecimento elocutório, ação restrita e transposição, traduzidos simetricamente em Deserto, flauta seca, Acaso, Tebas. Porém, se no caso de Mallarmé é certo que se pode interpretar a negação como um jogo mortal e vital, no caso de Valéry, inversamente, a aparente radicalização do gesto que repercute concêntrica e infinitamente na desvalorização repetida do real e do humano não impede, entretanto, a referida pretensão de estética universalista, que se abriga ainda sob o poder puro de uma consciência racional claramente reivindicada. É precisamente o poder de negação da história e das culturas enquanto valores, por um lado, que prescreve, por outro lado, o valor de universalidade da negação enquanto poder espiritual.

Neste sentido, a Fábula é o poema de um frágil que fragiliza a estética racional, apresentando-se como desconfiança histórica desta estética: 
isto é, como desconfiança da desconfiança da história que esta estética reivindica. E ainda, como posição de historicidade e postura de leitura de um Anfíon que vai ao Amphion, peça musical de Valéry, e deste à Histoire d'Amphion, onde o francês expõe em forma de conferência os princípios estéticos que dominaram o projeto da peça, e que inversamente não dominam o não-projeto do poema cabralino.

Em Amphion, Valéry inventa um herói inspirado em sonho por Musas apolíneas; convida o Astro a contemplar os efeitos de seu poder criativo, compõe o famoso hino ao Sol. Na conferência Histoire d'Amphion, Valéry explicita publicamente (numa atitude de confissão racionalista herdada do Poe de Philosophy of composition) como nasceu a peça. Foi a partir de uma dupla convicção, em primeiro lugar da ahistoricidade da verdade do mito, e em segundo lugar da possibilidade de correspondência estrutural entre as artes - apenas as que não são miméticas. Resumidamente, afirma Valéry que o mito grego de Anfíon, onde se narra a construção dos muros de Tebas ao som da lira do herói, não teria feito mais do que exprimir intuitivamente uma verdade estética universal: a da vocação antimimética comum à música e à arquitetura, capazes ambas de "construir sem imitar". A consequência disto, é a demonstração da vocação antimimética da poesia simbolista, na medida em que o simbolismo pode ser a união da música do significante com a estrutura poética do significado, contanto que obedeça por sua vez à regra de não mimetizar, e se refira apenas àquilo que desde sempre já é universal, isto é, à verdade alegórica do mito. Aqui, a relação entre mito e poesia é de fato circular, tautológica e alegórica: sendo verdade eterna, o mito antecipa e torna possível o simbolismo, o qual por sua vez é a sua autêntica revivescência poética. Tudo se refazendo pela alegoria - isto é, pela postura antimimética frente à narrativa do mito, cuja verdade, ou a quintessência, ressurge na poesia simbolista, ela mesma lembrança do mito, etc.

Quase nem é preciso argumentar: sabemos todos que João Cabral, aqui mesmo, neste poema carente de Tebas artefato, onde estranhamente tanto já se leu sua fidelidade ao racionalismo negativo, diverge tangencialmente deste Valéry; mas a divergência, profunda e dita em excesso, insistentemente, lê-se nos contornos disponíveis da recepção e não nos signos do texto cabralino. Na recepção, onde podemos e devemos escolher nossas questões: relações de Valéry e de Cabral com a tradição literária transmissora do mito, e mais exatamente dos mitos de Anfíon, mas também relações entre João Cabral e Valéry através da leitura de um por outro, nossas leituras de ambos etc.

Como quer que seja, argumentemos: se o Anfíon cabralino não queria Tebas criada ao som da flauta, mais do que a recusa da música, isto está 
dizendo que a verdade estética não pode ser eterna e nem se deposita nos signos. A música recusada, longe de ser a do lirismo, é a da Musa que projeta universalizar a música. É portanto a do próprio simbolismo bifronte: metade mistério e metade razão, ou melhor, mistério definido como tal pela própria razão. Antepondo-se, de corpo e alma - isto é, no ritmo do poema, contra a postulação de universalidade valéryana, com a consciência de que Valéry nunca deu e nem daria crédito a vozes de historicidade radical, o pernambucano está imprensando contra a parede um discurso que se revela absurdo para qualquer um que não se sinta nem viva como ser universal.

Na Fábula pernambucana, eu diria que o mito grego está portanto em posição de ser sutilmente falso, mas não porque a música não possa criar nada por essência. E sim por força de sua revisitação valéryana deformadora. Ou seja, por causa do que a Poética fez com a música e com a poesia. Pois foi exatamente passando por Valéry que o mito grego (o qual, como todo mito, jamais foi história real), passou a ser parte da história real. Quando a irrealidade passada do mito foi transformada em eternidade da verdade do mito, a universalidade se particularizou, e o particular se universalizou, tornando Valéry uma herança problemática, sob forma de um discurso a-histórico paradoxalmente historicista por negar-se a ser historicidade. Anfíon - pernambucano malcriado, e Acaso história desobediente criando ao som de outra flauta, podem ter-nos dado o poema que faz o que diz, recusando, pela consciência de historicidade, a união conivente entre o mito que falseia e a poesia que mitifica. Entre Mito e Poesia.

Mas relendo o mito - o grego -, sempre se descobre alguma novidade encoberta pelo trabalho de mitificação. No caso, leiamos que Anfíon, o grego, jamais criou Tebas (OVÍDIO, III, 1-137). O germe do enigma histórico já está nisto - no fato que não há fundação absoluta, nem origem de nada. Nem é isto que define o poema. E Cabral compõe: quando a flauta soou, um tempo se desdobrou do tempo, como uma caixa de dentro de outra caixa. Não ocorre a dupla, nem a tripla traição de que nos fala Sebastião Uchoa Leite quando afirma que "Na Fábula de Anfion, (...) há uma dupla 'traição', ao mito original e a Paul Valéry, ou tripla, ao ter-se por inclusa a 'traição' anterior a Mallarmé” (UCHOA LEITE, 1986, p. 117). Precisamos combater a ideia de um João Cabral super-homem capaz de fazer o mundo sozinho, órfão de tradição e cultura. O que existe é uma leitura frágil de Valéry, a qual se apoia no sentimento de insubmissão à verdade humilhante do preceito racional, onde nenhum Cabral pode começar a existir, posto que tudo está dito desde a origem. No mito grego acontecido na leitura de João Cabral, lê-se a narrativa da passividade histórica indestrutível 
e intransferível: pois o problema do Anfíon cabralino não é criar Tebas nenhuma; é sobreviver ou não, continuando o que aí está. Ora, isto que aí está de certa forma se aprende no mito grego e não se repete; por isso, aí está igualmente, sob forma de problema e solução, o mito grego de Valéry, e o valor da história de Cabral, que não é um mito.

\section{Realidade do passado}

Qualquer interpretação da história enquanto realidade ou irrealidade passada coloca a questão do ser diferente, e do ser semelhante: "Nous disons quelque chose de sensé sur le passé en le pensant successivement sous le signe du Même, de l'Autre et de l'Analogue". (RICEUR, 1985, p. 205). Se a narrativa ficcional é resposta à passividade frente ao tempo, enquanto categoria cósmica legível em marcas do passado, a Fábula cabralina dedicase à paixão do ser semelhante e do ser diferente. Em outras palavras, a condição de historicidade, surgida como resposta a uma tradição moderna de poesia (a de Valéry), não se sustenta sem uma posição de carne e osso que é o próprio poema, e o que ele faz. Todo o problema da Fábula de Anfíon é que sua historicidade, tão presente, no entanto não se desvenda por fácil decifração, estilizando-se na mordida enigmática de Anfíon por uma cachorra que aparece roendo seu osso antigo. Sua história, convocada como insistência na história, é ao mesmo tempo insistentemente proibida. Seu ser semelhante e ser diferente não se confessa abertamente.

É que o poema transfere para o leitor a tarefa de ser semelhante e de ser diferente, apelando para a dimensão concreta do mundo real, suspensa ao vocativo da Fábula. Espaço vocativo que avulta como desejo de inclusão do mundo do leitor no mundo do texto, por injunção que se faz através do artifício elementar da forma interrogativa dos dois últimos segmentos. A série pungente e angustiante de perguntas sem respostas - uma flauta, como dominar...? não deixa de surtir este efeito, de que as respostas (ou não respostas) a estas perguntas dependem do leitor. Solicita-se a escolha entre o consolo do herói e o sentimento de impotência ante sua fragilidade, tornada então, neste momento, a própria fragilidade do leitor ${ }^{6}$. Isto é, se eu não sei responder, é porque minha condição de historicidade também me condena a estar sem saber. Ora, o poema não quer que eu responda, e

\footnotetext{
${ }^{6}$ Em Imaginando João Cabral imaginando, manuscrito inédito, um papel de destaque é atribuído ao sentimento, que na obra do pernambucano não joga o papel de obscura sensualidade, e sim de apelo à fragilidade que se converte em força poética.
} 
por isso mesmo inclui a pergunta. Pois, de fato, por que perguntar? O que é que se está perguntando? A quem? Se João Cabral "abre esta janela" em direção do leitor, é para articular sua própria posição de historicidade com a perplexidade do herói que não sabe como fazer, e com a perplexidade histórica do leitor que não sabe responder.

Minha leitura é que João Cabral, acolhendo a história na Fábula de Anfíon, e recusando as determinações de sua própria história, ao se acertar com Valéry sobre a questão histórica, está fazendo mais do que se acertar com Valéry. $\mathrm{O}$ acerto tropeça na sua singular passividade frente ao tempo passado. Tudo se passa como se certa passividade impossível de ser assumida como discurso (não a quisera...), precisasse no entanto de reconhecimento articulável, resultando na pergunta: como fazer? Em suma, o sentimento de posição na história não se reduz, nem se deduz. Não se resolve, mas é posição falável, e particularmente poetizável. Assim, a situação de Anfíon só pode ser entendida pelo leitor do poema. Não se teoriza, não é regra, nem ilustração de verdade. Nada desvenda conceitualmente. Não quer se comprometer com uma verdade universalizável nos moldes do pensamento abstrato. Em suma, pede ao leitor um olhar já desconfiado de Valéry, ao pedir a inclusão do passado no poema: Anfíon chega ao deserto.

É possível explorar várias consequências poéticas desta divergência tão fundamental entre os dois poetas ${ }^{7}$. Hoje, tento a seguinte pergunta: mas por que o leitor de João Cabral não atende ao pedido, assumindo a universalidade como problema também para si, e lendo o poema como resistência crítica contra o universal? Veja-se, como exemplo, o estudo detalhado da Fábula por José Guilherme Merquior (MERQUIOR, 1997), o primeiro a mostrar que o poema cabralino não se resolvia apenas pelo ângulo de uma fenomenologia da criação restrita ao problema da linguagem, e considerada abstratamente como luta pela expressão. $\mathrm{O}$ perfil anfiônico, segundo Merquior, traz as marcas da ambivalência de João Cabral frente ao tempo. Diz ele:

Anfíon (...) envida todos os esforços para conquistar o tempo e banir a ação da fortuna, e, não obstante, não só seu poema depende da indomabilidade do tempo, como seus próprios esforços parecem reclamá-la, parecem tender para ela. (MERQUIOR, 1997, p. 149).

${ }^{7}$ Cf. HENRIQUE DA COSTA, Cristina. João Cabral de Melo Neto: de l'homme qui vient à l’image. Tese de doutorado. Montpellier: Paul Valéry Montpellier 3, 2002. 
Porém, esta pertinente e criativa observação não o levou à consciência de sua historicidade própria, e ele não chegou a aplicar a si mesmo isto que parece ser uma lei da autoimplicação do pensamento histórico, enquanto consciência afetada pela impossibilidade de pensar, em termos hegelianos, a mediação total. Como prova disto, reporto-me às conclusões do artigo (sob o título de Modernidade da visão cabralina) onde leio duas afirmações que não seriam contraditórias caso o articulista houvesse aplicado a si mesmo o que estava tentando ler no poeta, isto é, a indomabilidade do tempo. Pois Merquior admite que a interpretação da Fábula de Anfíon implica um autor-leitor da história (que ele acredita ler no texto), mas não admite que esta mesma interpretação precise também de um leitor imerso na história (pois ele não admite que está também, ele próprio, lendo fora do texto, a partir da história).

Numa primeira fase, afirma:

Como todo poema de primeira grandeza, a Fábula continuará a suscitar interpretações e reinterpretações. Em lugar da "veleidade" de tê-la decifrado inteiramente, guardamos apenas a convicção (talvez infundada neste ou naquele ponto) de haver tentado compreendê-la a partir dos dados do próprio texto. Nosso entendimento poderá sem dúvida ser posto em causa, mas qualquer discussão será obrigada a articular-se neste mesmo terreno: o da soberana prova do texto. Esta, antes de todas as outras, tem que ser a disciplina - ou, para falar com Anfíon, a "respiração do deserto" do crítico. (MERQUIOR, 1997, p. 146)

Logo adiante, porém, acrescenta: "Sua atitude" (está tratando da atitude de João Cabral frente à Fortuna, isto é, frente ao Acaso enquanto categoria histórica moderna ocidental) "poderia ser melhor definida se a contemplássemos na perspectiva da história da cultura"8. Ora, esta passagem dos recursos de leitura do texto para os recursos de leitura da cultura equivale precisamente à passagem da retórica à hermenêutica, contanto que alcançada explicitamente e com consciência crítica. Sintomaticamente, Merquior recorre à lei normativa de leitura (afirmando que a prova da verdade está no texto), ao mesmo tempo que apela para a efetividade da história (afirmando a inteligibilidade do poema através do conceito de Fortuna), porém não se demora na necessidade de articulação destas duas coisas, no entanto indissociáveis.

De fato, não há Fortuna possível para João Cabral sem Fortuna para José Guilherme Merquior, e parece lógico postular que a compatibilização

\footnotetext{
${ }^{8}$ Neste ponto preciso a referência de Merquior é Montaigne.
} 
do texto poético do pernambucano com sua "janela de leitura" (sem dar ao termo de história da cultura uma significação historicista, como se soubéssemos cientificamente o que é a história da cultura), implica numa reflexão sobre a própria historicidade do leitor. Pois ad infinitum nossos esforços para banir a Fortuna (da nossa leitura do poema de João Cabral, por exemplo) dependem no entanto igualmente da indomabilidade do tempo para a qual tendemos (no ato de leitura). No poema, o próprio Acaso, força de cavalo, inseto vencendo o silêncio, esfinge, cachorra de esfinge, já é imagem da resistência contra o desvendamento abstrato - isto é, resistência desta condição de historicidade comum que está sintomaticamente colocada no centro do poema.

Mas há ainda algo, além do reconhecimento comum (autor e leitor) da historicidade no poema. É que a indomabilidade do tempo lê-se então na ambivalência mais profunda de João Cabral ante o acontecido; e o problema é que não se explica esta ambivalência apenas com teoria da cultura. Na verdade, o poema Fábula de Anfíon desvela-se violento, posto que resistente: João Cabral, quando amputado de sua violência metafórica própria, sucumbe à violência de suas fatais abordagens teóricas. Creio porém que não se possa dominar por muito tempo a cachorra para que ela não saia mordendo na carne e no osso. Ela mordendo, morde a imagem, mordendo a imagem, morde o Acaso, mordendo, o Acaso morde. Lida na violência metafórica, a história ataca, repentinamente, como um raro animal, força de cavalo, cabeça que ninguém viu, e, claro: cachorra, cachorra, cachorra. Há um drama de um tempo (que não é "o tempo"), remoendo no poema. Ora um tempo, só pode ser de fato o que acontece e aconteceu: aquilo que a fenomenologia de João Cabral não sabe, não pode, e nem quer domar. Por isto o Acaso do poema ataca no instante (cósmico, mundano, vulgar) que foge ao controle da alma. O instante é a violência concreta do incomensurável que dobra a fenomenologia da criação - que rende a alma quando a alma se rende.

Neste preciso drama de Anfíon, que Merquior não leu como instante "dramático" e sim como recusa ativa de sofrer o tempo 9 , vejo em todo caso, lendo o poema como organização rítmica subjetiva, uma lição de passividade.

Il faut écouter, venant de plus loin que Platon, l'invincible parole qui, avant toute notre philosophie et malgré toute notre phénoménologie de la conscience du temps, enseigne que nous ne produisons pas le temps, mais qu'il nous entoure,

9 "Anfíon só justifica o destino recusando-se a sofrê-lo passivamente" (MERQUIOR, 1997, p. 145). 
nous encercle et nous domine de sa redoutable puissance. (RICEEUR, 1997, p. 27) ${ }^{10}$

Arrisco-me então a sugerir que a passividade cabralina revela-se aqui dramática não apenas pela humilhação teórica de o herói-poeta não ser espírito puro e criador do tempo humano. O poema vai além: no debate moderno entre vertentes românticas (o papel excepcional do poeta...) e vertentes anti-românticas (desmistificando o indivíduo poeta...) fica sempre de fora o momento da passividade concreta e real deste poeta, neste poema, em relação à sua história em especial. Se, na Fábula de Anfíon, a passividade frente ao tempo se esconde por trás do gesto de recusa do herói, quando ao final da narrativa joga a flauta aos peixes surdos-mudos do mar, é possível entretanto reconstituir a significação deste gesto a partir do momento em que ele nasce: ante a Tebas que não foi criada por ele, mas existe, e ante a morte valéryana de Amphion, que o gesto racional sequer salvou. Age-se ante o passivo, mas agir no poema, sobrevivendo à morte previsível, significa reconhecer a realidade histórica do passado mesmo que reconhecido como negativo.

Costuma-se pensar a relação de João Cabral com “a tradição" pelo prisma básico da crítica das ideologias, que tanto resulta no pensamento da recusa da autoridade "da tradição" (subentendida como um bloco monolítico) quanto na estética moderna da ruptura em relação às formas artísticas do passado. Em ambas está em causa e em questão o valor de verdade do passado, mas em ambas o questionamento deste valor permanece abstrato e teórico enquanto não se articula com a questão fundamental da realidade da vivência, ou revivescência do passado, isto é, com a questão do peso de realidade da passividade que se imprime em palavras ditas e em marcas concretas, testemunhos da passagem do passado. Poemas. É justamente a necessidade de conservação do passado real que se dá na Fábula, em ritmo de preservação. A construção de muralhas ao redor de Tebas, para retomar o sentido aproveitável do mito grego, esboça os contornos de uma relação tensa com a história acolhida e protegida do resto.

Reconheço a dificuldade desta leitura da Fábula, quando tenta passar da indomabilidade comum do tempo para a subjetividade radical do indomado. Ler certa presença negativa do passado no poema de João Cabral é querer definir a relação poética anfiônica pelo prisma de um tempo imaginável, de uma significância sem localização semiótica: não é o

${ }^{10}$ A reflexão de Ricœur apoia-se aqui em um fragmento de Anaximandro. 
negativo objetivo do passado em geral, e não é a apreensão fenomenológica do tempo pela consciência. É o discurso de um tempo passado, não como categoria do pensamento racional, e sim como posição vital, rítmica e crítica: força de cavalo, cabeça que ninguém viu, camelo sobrevivendo à sede etc. Nada aqui é recusado, a não ser o mito da poesia que recusa. A força, a cabeça, a sobrevivência continuam.

Este um tempo do passado cabralino também pode ser lido num ovo podre.

Será que pesa mais o real/ quando em defunto, em pantanal? Indaga o poeta n'O ovo podre (MELO NETO, 1994, p. 580). O que sugere a associação entre o passado, real defunto, e a podridão negativa, é precisamente o fato que aquilo que não se vê (pois o ovo podre não difere, à vista, de qualquer outro) no entanto pesa mais do que todos os podres do mundo. Não se vê, mas não se trata absolutamente de livrar-se do ovo podre. Pois isto que não se vê pesa mais. Da mesma forma que a crítica das ideologias ajuda a matar e enterrar bem enterrado o passado negativo sob o olhar de distância da racionalidade crítica, corre também o risco de não enxergar na Fábula de Anfíon que o negativo que houve e não pode ser visto, muito maior do que o negativo que ele em geral faz ou teoricamente poderia fazer, é o ponto de fuga do herói cabralino ante aquela cidade que ele não quisera assim.

Paulatinamente, a leitura de Fábula de Anfíon pode então conduzir a tudo inverter. Nem mesmo aqueles peixes surdos-mudos foram escolhidos pelo pensamento crítico discriminante; ao contrário, separaram-se dele num jogo metafórico que revela o enjoo frente à previsibilidade que a estética racional imprime até mesmo ao irracional: suas mortes, seus nadas, seus vazios. Anfíon chega no poema vindo de um lugar desconhecido, e se detém num Deserto que lhe é familiar pela capacidade de negação de tudo. Quando vem o Acaso, não se sabe de onde, Tebas surge como imprevisto. Mas tudo isto é previsível, e logo, reversível. Neste sentido, o herói também pode estar vindo do que lhe é familiar; perdendose no Deserto. O Acaso é o de sempre, e Tebas será sobretudo temida por conhecida demais. Perdido no labirinto da reversibilidade dos discursos tautológicos, o poema busca o passado real negativo (o avesso) como término do processo de negação racional. A cachorra da esfinge que lhe mordia a mão escassa, que lhe roía o osso antigo, logo florescido morde então num osso que se revela cheio de coisas opostas, e por isso mesmo, equivalentes: simbolismo e romantismo; ideologia e crítica da ideologia, universalidade e realidade regional. O poema é, no fundo, o palco mudo para um gigantesco conflito de tradições incendiado por alma afetada pelo sentimento do passado. 
Neste quadro ambivalente, que como simples nozes cuja noite encerrada à luz e ar-livre persiste, é preciso saber por fim se o sentimento do passado negativo tem força poética e consistência estética. Não é inútil lembrar aqui o conflito, no pernambucano, entre o passado real e o passado mítico da estética simbolista. Ora, João Cabral, buscando a ultrapassagem da fixação no/do signo, obstáculo para a digestão antropofágica do simbolismo francês, adotou a imagem surrealista quando não se convenceu com a redução do poema à dualidade conceitual-musical do significado e do significante. A postura traduz a recusa de condenar a história humana a ser uma ruminação etimológica, da qual a poesia seria a servil memória - relógio marcando horas que ninguém vivera ${ }^{11} .$.

E para concluir, pode-se tentar começar: Anfíon, no segmento pelo qual este artigo principiou, segue procurando; como vimos, não há nada, no sentido de objeto, para procurar; não se trata de voltar ao deserto; não se trata de regressar; não é atitude de regressão, nem ao menos se quer destruir Tebas, fazê-la ou refazê-la: apenas, em meio aos restos de coisas marcantes do passado, o seguir procurando aponta para a capacidade de imaginar e dizer um passado negativo, prescrito, proscrito e escrito. Alguma coisa que, como sugere Henri Meschonnic, discurse sobre o sujeito em ritmo, radical na história, falando de eu para eu, e convidando o leitor a ler no ritmo, traduzindo, pulando pela janela, para fora da retórica do poema.

\section{REFERÊNCIAS BIBLIOGRÁFICAS}

BARBOSA, João Alexandre. A imitação da forma: uma leitura de João Cabral de Melo Neto. São Paulo Livraria Duas Cidades, 1975.

COSTA LIMA, Luiz. Lira e Antilira: Mário, Drummond, Cabral. Segunda edição revista. Rio de Janeiro: Topbooks, 1995.

CHARLES, Michel. Rhétorique de la lecture. Collection Poétique. Paris: aux Éditions du Seuil, 1977 .

FERRAZ, Eucanaã. Máquina de comover: A poesia de João Cabral de Melo Neto e suas relações com a arquitetura. Tese de doutorado. Rio de Janeiro: UFRJ, 2000.

GLEDSON, John A. Sleep, Poetry and João Cabral's "false" book: a revaluation of Pedra do sono. Bulletin of Hispanic Studies. Liverpool: LV, 1978.

${ }^{11}$ Ora, na sala do poeta o relógio/ marcava horas que ninguém vivera... (MELO NETO, 1994, pp. 52-53). 
HENRIQUE DA COSTA, Cristina. João Cabral de Melo Neto, de l'homme qui vient à l'image. Tese de doutorado. Montpellier: Paul Valéry Montpellier 3, 2002.

MELO NETO, João Cabral. Obra completa. Volume único. Rio de Janeiro: Editora Nova Aguilar, 1994 .

MERQUIOR, José Guilherme. A astúcia da Mímese: ensaios sobre lírica. Rio de Janeiro: Topbooks, 1997.

MESCHONNIC, Henri. Critique du rythme: Anthropologie historique du langage. Lagrasse: Verdier, 1982.

MEYER, Michel. Histoire de la rhétorique des Grecs à nos jours. Paris: Le livre de poche, 1999 .

NUNES, Benedito. João Cabral de Melo Neto. Segunda edição. Petrópolis: VOZES, 1974.

RICEUR, Paul. Temps et récit III : Le temps raconté. Paris : aux Éditions du Seuil, 1985.

SECCHIN, Antonio Carlos. João Cabral: A poesia do menos. São Paulo: Livraria Duas Cidades, 1985 .

UCHOA LEITE, Sebastião. Crítica clandestina. Rio de Janeiro: Taurus Editora, 1986.

VALÉRY, Paul. Introduction à la méthode Léonard de Vinci. Deuxième édition. Paris: Editions de la Nouvelle Revue Française, 1919.

. Euvres II: Pièces sur l'art, Histoire d'Amphion. Édition établie et annotée par Jean Hytier. Paris: Gallimard, 1960. 